\author{
DEPARTMENT OF COMMERCE \\ BUREAU OF STANDARDS \\ George K. Burgess, Director
}

TECHNOLOGIC PAPERS OF THE BUREAU OF STANDARDS, No. 310

[Part of Vol. 20]

\title{
PROPERTIES OF POTTERS' FLINTS AND THEIR EFFECTS IN WHITE-WARE BODIES
}

BY

E. E. PRESSLER, Junior Scientist, Engineer

W. L. SHEARER, Laboratory Assistant

Bureau of Standards

February 12, 1926

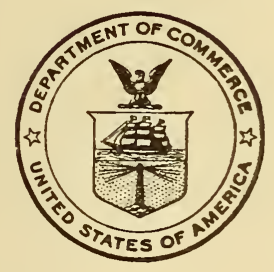

PRICE, 15 CENTS

$\$ 1.25$ PER VOLUME ON SUBSCRIPTION

Sold only by the Superintendent of Documents, Government Printing Office Washington, D.C.

WASHINGTON

GOVERNMENT PRINTING OFFICE 



\title{
PROPERTIES OF POTTERS' FLINTS AND THEIR EFFECTS IN WHITE-WARE BODIES
}

\author{
By E. E. Pressler and W. L. Shearer
}

\begin{abstract}
A report is given on an investigation of the physical and chemical properties of 17 commercial flints and of their effects in typical white-ware bodies. The flints were relatively pure silica with a small percentage of iron oxide and lime varying from zero to 0.45 per cent. Over 95 per cent of most of the flints would pass a No. 325 sieve and over 50 per cent a theoretical No. 1,000 sieve. Typical heat absorption and thermal expansion effects were found at the quartz inversion temperature and were roughly proportional to the percentage of free quartz in the samples. The firing behavior of the bodies is affected less by the type of flint used than by the fineness of the flint and the presence of impurities.
\end{abstract}

\section{CONTENTS}

290

II. Scope-_.

III. Nomenclature

IV. Properties of the flints.

1. Descriptive references to samples._._._._._._._. 291

2. Chemical composition

3. Mechanical analyses...-_._. 293

4. Specific gravity

5. Microscopic examination

V. Effects of silica inversions _...

1. The crystal forms of silica

2. Study of transformation heat effects_............. 299

(a) Method of observation._._._. 299

(b) Descriptive references_..._._. 299

(c) Heat effect curves . . . . .

(d) Analysis of transformation heat effect data...... 300

(1) Effect of types of flints....... 300

(2) Effect of fineness of flints

(3) Effect of crystal form of silica in white-ware bodies........ 301

(4) Effect of fineness of flint in white-ware bodies....... 303

(5) Peculiarities in heat effects.........- 303

(6) Effect of quartz solutions

3. Study of thermal expansion. 304

(a) Method............ 304

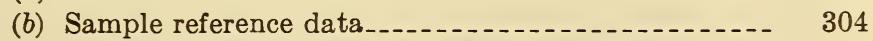

(c) Analysis of curve data on the thermal expansion of bodies

(1) Effect of type on body

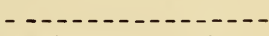

(2) Effect of type of flint contained in bodies.- 304

(3) Effect of crystal form of silica........- 307

(4) Effect of fineness of flint............. 307 
V. Effects of silica inversions-Continued.

4. Comparison of results of heat effect and thermal expansion studies

5. Study of resistance of bodies to thermal shock

(a) Tests for resistance to thermal shock . ......... 307

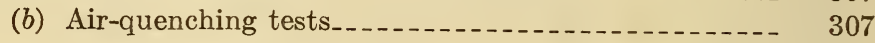

(1) Testing procedure

(2) Observations on air-quenching tests_..... 308

(c) Water-quenching tests_._._._._. 308

(1) Testing procedure....... 308

(2) Observations on water-quenching tests....- 308

(d) Conclusions_-_-_._. 308

VI. Effects of flints on the firing behavior of bodies._... 308

1. Relative fusibility in a "cone 4" body

(a) Body and batch compositions__._._._...... 308

(b) Testing procedure

(c) Results_........ 309

2. Draw trial study on a vitreous china body

(a) Preparation of test specimens.

(b) Method of firing

(c) Physical data

(d) Discussion of results..._._. 310

3. Effects of flints on physical properties of typical white-ware bodies

(a). Reference data

(1) 312

(b) Method of preparation 312

(c) Physical data_._._._._. 313

(d) Discussion of results_._._. 313

VII. Summary

\section{INTRODUCTION}

The appearance and service qualities of white wares are dependent primarily on the chemical and physical properties of the constituent raw materials. As a part of a general study of these raw materials, the Bureau of Standards has conducted an extensive investigation on potters' flints.

Potters' flint, or pulverized quartz, is that constituent in a burned white-ware body which promotes rigidity of structure. Its effect in body compositions is to reduce the drying and burning shrinkage and usually to promote refractoriness. Flint has an important bearing on the resistance of bodies to thermal and mechanical shock because of the volume changes which accompany its crystal transformations.

The investigation reported herein is the third of a series conducted by the Bureau of Standards on the composition materials of whiteware bodies. ${ }^{1}$ This series of investigations represents a cooperative effort of industrial and technical organizations interested in the pro-

1 A discussion of the previous work and a general outline of this series of investigations, presented by R. F. Geller, The Ceramist, 4, No. 6, pp. 375-380; September, 1924. 
duction of white wares. A report on the results of thermal expansion determinations included in this paper has previously been published. ${ }^{2}$

Recognition for work done in this investigation is due the following members of the Bureau of Standards personnel: H. C. Stecker, for chemical analyses; W. H. Sligh, for air analyses; Dr. Herbert Insley, for microscopic examinations; Dr. A. Q. Tool, for heat of transformation data; G. E. Merritt, for thermal expension data; and R. F. Geller and others, for advice and assistance in executing the laboratory work.

\section{SCOPE}

This report covers the results of (1) a study of the properties of 17 flints as shown by chemical analyses, physical determinations, petrographic examinations, and a study of inversion points as indicated by heat absorption and thermal expansion effects; and (2) a study of the firing behavior of typical vitreous and semivitreous white-ware bodies containing the different flints.

\section{NOMENCLATURE}

Geologically, flint is a hard rock of dense structure, showing conchoidal fracture and no apparent cleavage, and composed chiefly of cryptocrystalline quartz or amorphous silica. According to Washburn and Navias, ${ }^{3}$ flint consists of quartz crystals of microscopical or submicroscopical size which are so small that they may be considered to have colloidal properties.

In ceramic usage the term "flint" has been extended to include any form of quartz used in ceramic bodies. The macrocrystalline, or relatively coarse crystalline form of quartz, is more generally used for preparing potters' flints than the cryptocrystalline form. The term "true" flint has, therefore, come into use to apply to flint prepared from cryptocrystalline quartz, while the term "quartz" is commonly applied to flints prepared from macrocrystalline quartz.

Quartz flints are generally produced in America for the domestic market and the cryptocrystalline, or true flints, imported from France. The quartz flints are prepared from quartz rock, sand, or sandrock, and the cryptocrystalline flints from pebbles of cryptocrystalline quartz. The latter are of marine origin and often vary in color and purity.

\section{PROPERTIES OF THE FLINTS}

\section{DESCRIPTIVE REFERENCES TO SAMPLES}

Data descriptive of the samples are listed in Table 1.

The groups Nos. 13, 14, 15, and 16, and Nos. 7, 9, and 17 are from common sources, but ground to different degrees of fineness and marketed under different trade names. Nos. 14,15 , and 16 are pre-

\footnotetext{
2 "Effect of flints on thermal expansion of white-ware bodies," W. L. Shearer, The Ceramist, 4, No. 3 pp. 143-165; June, 1924.

3 "The products of calcination of flint and chalcedony," Washburn and Navias, Jour. Am. Cer. Soc., 5, No. 9 , pp. 565-585; 1922.
} 
pared by water flotation, No. 16 being the finest and marketed for special use as a filler in paints, etc. The raw materials are calcined in some cases to facilitate crushing, but this treatment probably does not cause any permanent change in the crystalline form.

TABLE 1.-Flint sample reference data

\begin{tabular}{|c|c|c|c|}
\hline $\begin{array}{c}\text { Lab- } \\
\text { ora- } \\
\text { tory } \\
\text { num- } \\
\text { ber }\end{array}$ & Source & Type & Treatment \\
\hline & Illinois & Cryptocrystalline & \\
\hline & France. & - & $\begin{array}{l}\text { Pebbles; calcined and crushed with chaser mill and } \\
\text { pulverized in ball mill. }\end{array}$ \\
\hline $3 \ldots$ & Pennsylvania _ & Sand quartz.- & Glass sand; washed, dried, crushed, and pulverized \\
\hline 4 & Virginia_- & Rock quartz .. & Massive rock; calcined, crushed with chaser mili, \\
\hline & Illinois_.-.- & Sand quartz & $\begin{array}{l}\text { and pulverized in ball mill. } \\
\text { White sand; pulverized in ball mill. }\end{array}$ \\
\hline & West Virginia & Sandrock quartz & $\begin{array}{l}\text { Hard sandrock; ground in continuous feed and } \\
\text { discharge ball mill until not more than } 2 \text { per cent } \\
\text { will remain on a No. } 160 \text { sieve. }\end{array}$ \\
\hline & $\begin{array}{l}\text { Pennsylvania } \\
\text { Illinois_....... }\end{array}$ & Sand quartz & Sandstone; washed, crushed, and ground in ball mills. \\
\hline & Penncylranis & Nand quatuat & $\begin{array}{l}\text { pebbles against Danish flint lining until } 98 \text { per } \\
\text { cent will pass a No. } 200 \text { sieve. }\end{array}$ \\
\hline $\begin{array}{l}9 \\
10 .\end{array}$ & $\begin{array}{l}\text { Pennsylvania.-- } \\
\text { Illinois...-..--- }\end{array}$ & $\begin{array}{l}\text { Sandrock quartz } \\
\text { Cryptocrystalline.-. }\end{array}$ & $\begin{array}{l}\text { Sandstone; washed, crushed, and ground in ball mill. } \\
\text { Amorphous rock; water ground and water floated to }\end{array}$ \\
\hline $11 \ldots$ & France...-. & 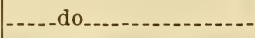 & $\begin{array}{l}\text { pass a No. } 180 \text { sieve. } \\
\text { Bowlders; calcined, crushed, and then ground in }\end{array}$ \\
\hline $12 \ldots$ & North Carolina... & Sandrock quartz & Massive rock; blasted, calcined and crushed, and \\
\hline $13 \ldots$ & West Virginia..... & -..._do... & $\begin{array}{l}\text { Sand or sandrock; crushed, washed, and dried. } \\
\text { Pulverized in tubular mills to pass Nos. } 120 \text { to } 220 \\
\text { sieves. }\end{array}$ \\
\hline 14 & - & 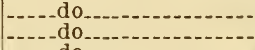 & $\begin{array}{l}\text { Sandrock quartz; water floated for separation into } \\
\text { very fine grade for use in the manufacture of wood }\end{array}$ \\
\hline & - ndo & -----do & fillers, paint, silver polish, etc. \\
\hline & & & Sandstone; washed, crushed. and ground in ball mills. \\
\hline
\end{tabular}

\section{CHEMICAL COMPOSITION}

The chemical compositions of the different flints are shown in Table 2. The analyses show that most of the commercial flints are relatively pure $\mathrm{SiO}_{2}$, the content being in excess of 99 per cent in most cases. Less than 1 per cent of $\mathrm{Al}_{2} \mathrm{O}_{3}$ is found in all samples except No. 3, which contains 2.52 per cent. Microscopic examination indicated 5 to 10 per cent of impurities in this sample, which appeared chiefly as orthoclase and microcline feldspars. $\mathrm{Al}_{2} \mathrm{O}_{3}$, however, is not important as an impurity, as it is generally required in a ceramic body, but its presence in flint should be taken into account when making up a body composition. $\mathrm{Fe}_{2} \mathrm{O}_{3}$ was found in all flints, varying from 0.03 to 0.12 per cent. While iron is objectionable as an impurity because of its discoloring effects, the small percentage present in the flints would probably be of no significance in a body 
composition. Some of the American flints are free from $\mathrm{CaO}$, and others contain generally less than the French flints. The loss on ignition varies from 0.13 to 0.85 per cent and represents $\mathrm{CO}_{2}$, dissociated from $\mathrm{CaCO}_{3}$, and adsorbed or chemically combined water.

TABLE 2.-Chemical compositions of fints

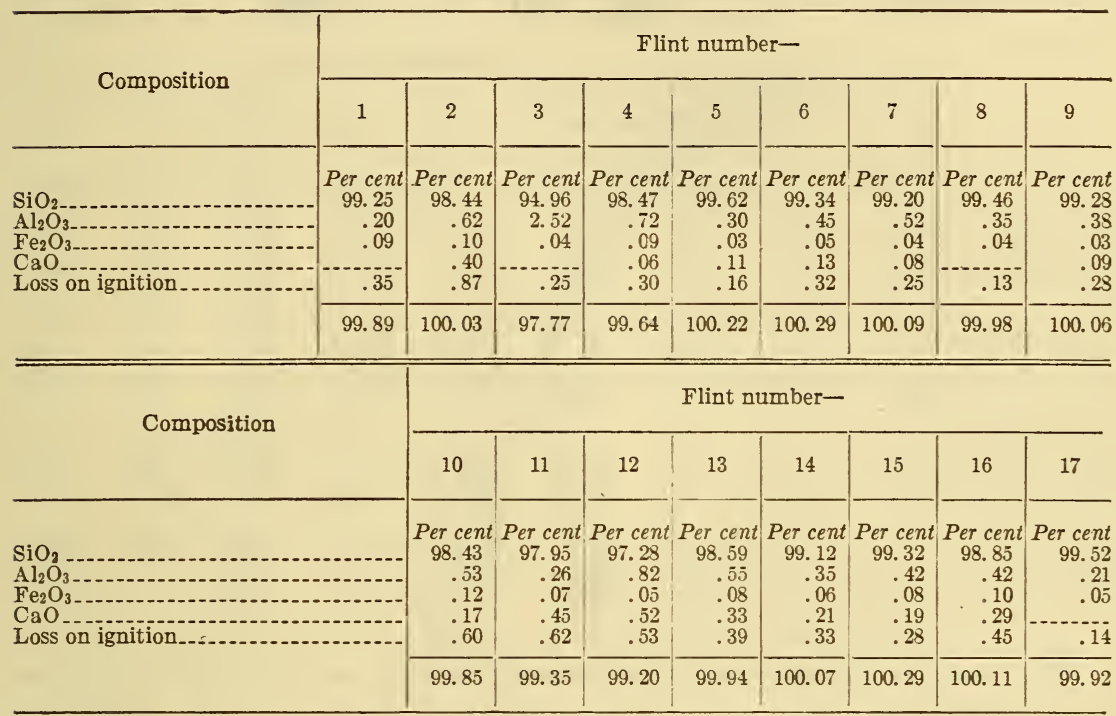

The impurities in flints generally act as fluxes, due to eutectic developments, and in this regard are not objectionable. They may, however, promote the transformation of quartz to cristobalite, which is undesirable because it may proceed to varied degrees in a fired body and affect the strength and glaze fit. Lime is probably the most active impurity promoting the transformation.

\section{MECHANICAL ANALYSES}

Mechanical analyses were made by sieve classification and air separation. The results are shown in Table 3 and Figure 1.

The sieve classification was made by the wet method, and separations were made on Nos. 100, 200, and 325 sieves. The "fines" were first passed through the No. 325 sieve and the residues separated on the Nos. 100 and 200 sieves. The testing procedure, however, was found slow, and the checking of results rendered difficult in some cases by agglomeration of fine particles. 
$\mathrm{T}_{\mathrm{ABLE}}$ 3.-Fineness classifications of fints

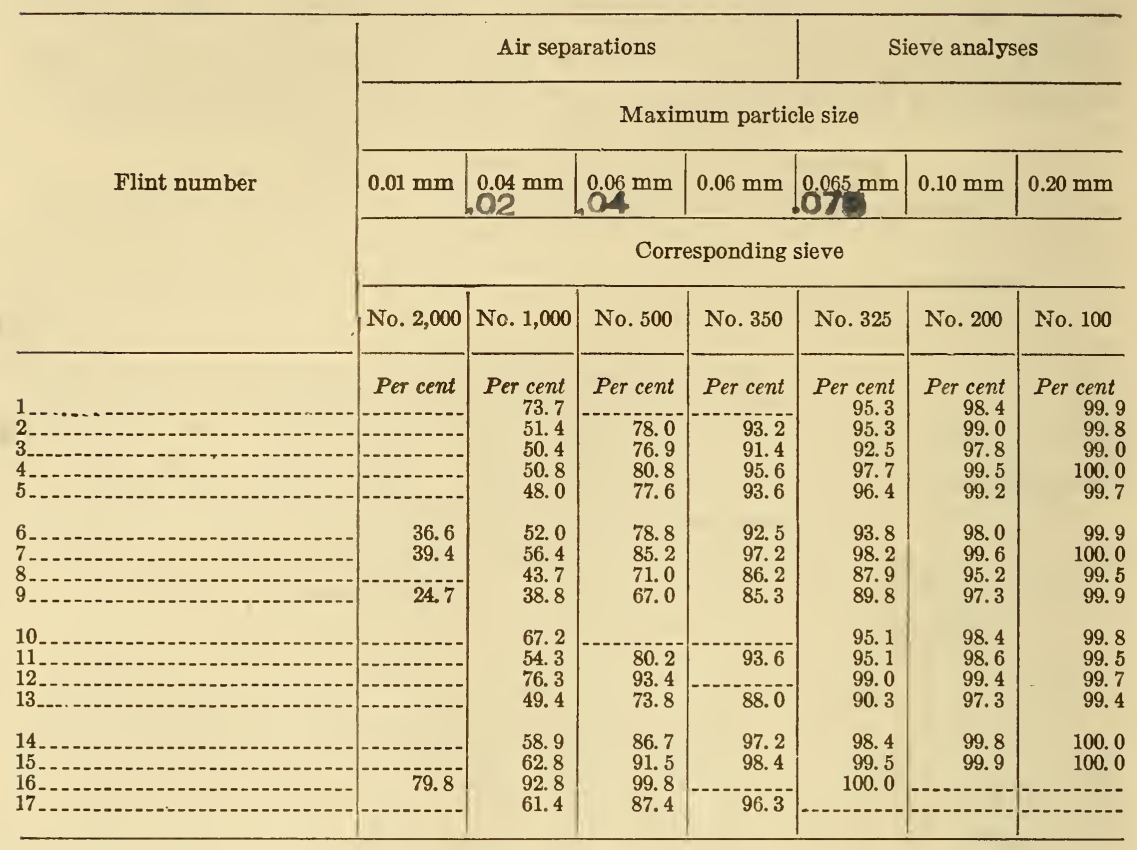

The sieve analysis was also unsatisfactory in that about 95 per cent of the material passed through the. No. 325 sieve, so that a distinct classification of particle sizes was not effected by this means.

To separate the fine particles into fractions, water elutriation may be used, but this method requires considerable time and attention. An air elutriator ${ }^{4}$ was found satisfactory in operation and gave results which could be closely checked. In this form of elutriator there is practically no abrasion or breaking up of particles, and the personal factor prominent in the sieve analysis is eliminated.

The separations are listed in Table 3 according to the limiting diameter of the particles included. ${ }^{5}$ The sieve numbers corresponding to the various classifications are also given. ${ }^{6}$

Relative fineness of the flints is shown graphically in Figure 1. In the case of Nos. 1 and 10 only one separation by the air analysis was obtained; but since the curves do not, in general, cross each other, the relative position of the fineness curves may be inferred from the location of the single points.

\footnotetext{
"An Air Analyzer for Determining the Fineness of Cement, J. C. Pearson and W. H. Sligh, B. S. Tech. Paper No. 48.

${ }^{5}$ The maximum size of particles included in the different classifications was determined by measurement with a micrometer microscope. The maximum diameter of particles passing the standard sieves is found to be larger than the specified sieve openings, due to flat particles passing through their diagonal sections.

6 The sieve numbers given for the air analyses are calculated from the sizes of particles passing the Nos. 100 and 200 sieves. Standard sieves finer than No. 325 are not constructed, but the theoreticai sieve number references are convenient for the comparison of classifications of very fine particles.
} 
For routine testing an air separation of the fraction of particles finer than $0.02 \mathrm{~mm}$ in diameter, corresponding to a theoretical No. 1,000 sieve separation, supplemented by a No. 200 sieve separation, is recommended. The first would ordinarily include from 50 to 55 per cent of the material in the sample, and the latter would indicate the presence of any considerable amount of relatively coarse particles.

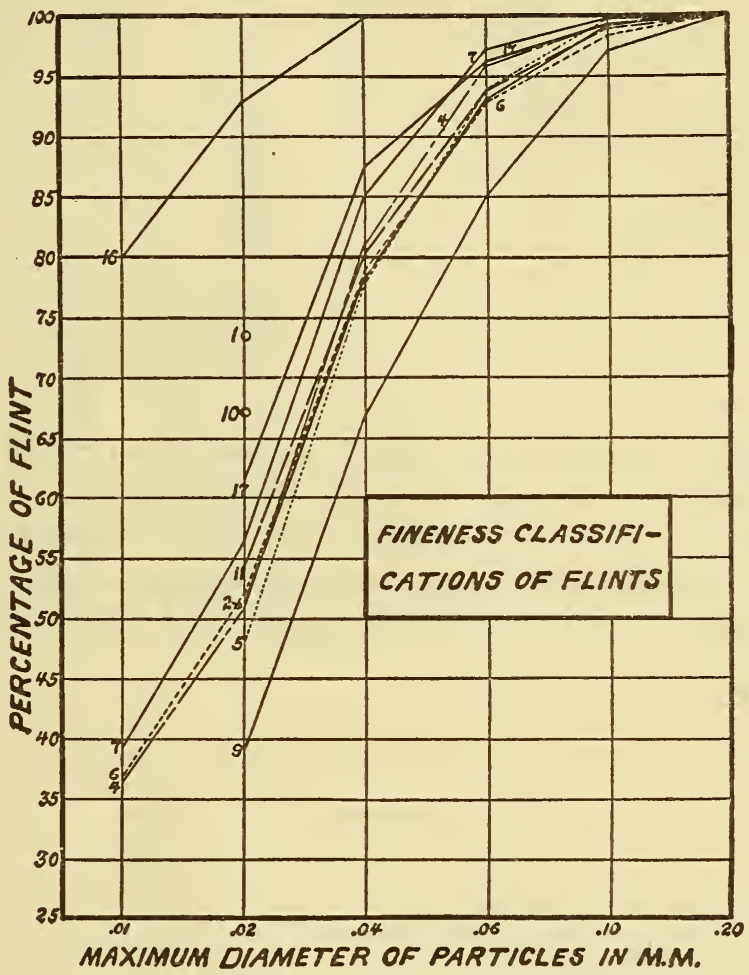

FIg. 1.-Variations in fineness of fint samples

\section{SPECIFIC GRAVITY}

The specific gravities of the flints as received and after calcination are shown in Table 4. These values were obtained by displacement in water at $25^{\circ} \mathrm{C}: \pm 0.05^{\circ} \mathrm{C}$., using a 25 cc pycnometer and a sample if about $4 \mathrm{cc}$. An electrically controlled water. thermostat was used for temperature control, and results were checked to two units in the third decimal place.

$$
68646^{\circ}-26 \dagger-2
$$


TABLE 4.-True specific gravities of fints

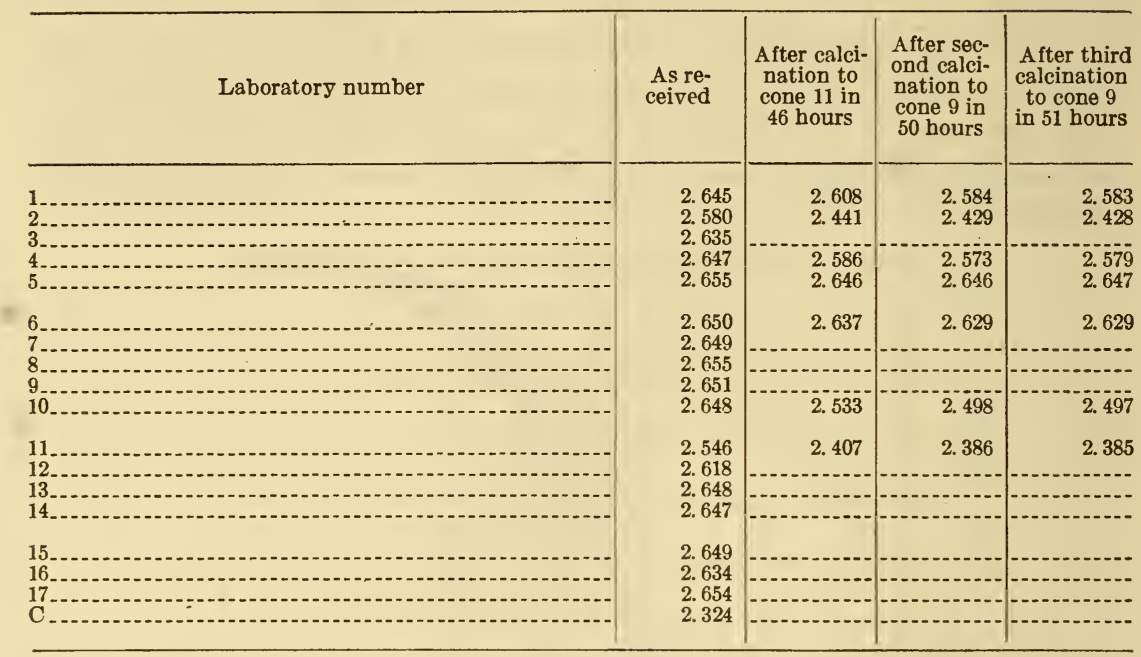

The specific gravities were found to vary from 2.655 for a flint prepared from a comparatively pure quartz sand to 2.546 for a French flint. In general, calcination was found to lower the specific gravity of cryptocrystalline flints more than quartz flints.

Below are given values for specific gravities of different commercial flints at $\frac{25^{\circ} \mathrm{C} \text {. }}{25^{\circ} \mathrm{C} \text {. }}$

\begin{tabular}{l|l|r}
\hline $\begin{array}{c}\text { Labora- } \\
\text { tory } \\
\text { num- } \\
\text { ber }\end{array}$ & Description & $\begin{array}{c}\text { True } \\
\text { specific } \\
\text { gravity }\end{array}$ \\
\hline & American sand flint (practically pure quartz) & 2.655 \\
\hline 7 & $\begin{array}{l}\text { American sand -rock flint (practically pure quartz) } \\
\text { American rock flint (quartz with some true flint) }\end{array}$ & 2.649 \\
\hline 1 & American cryptocrystalline flint (true flint) & \\
\hline
\end{tabular}

In general, the specific gravity of cryptocrystalline flints is lower than of quartz flints, but in some cases the difference is very slight.

\section{MICROSCOPIC EXAMINATION}

The descriptive data on a microscopic examination of the flints is shown in Table 5, together with the results observed on calcined flints.

All the flints showed slight color changes incident to calcination, and some became bonded together into a coherent, friable mass. It was observed also that cristobalite develops from calcination and that the transformation is greater in cryptocrystalline than in quartz flints. 


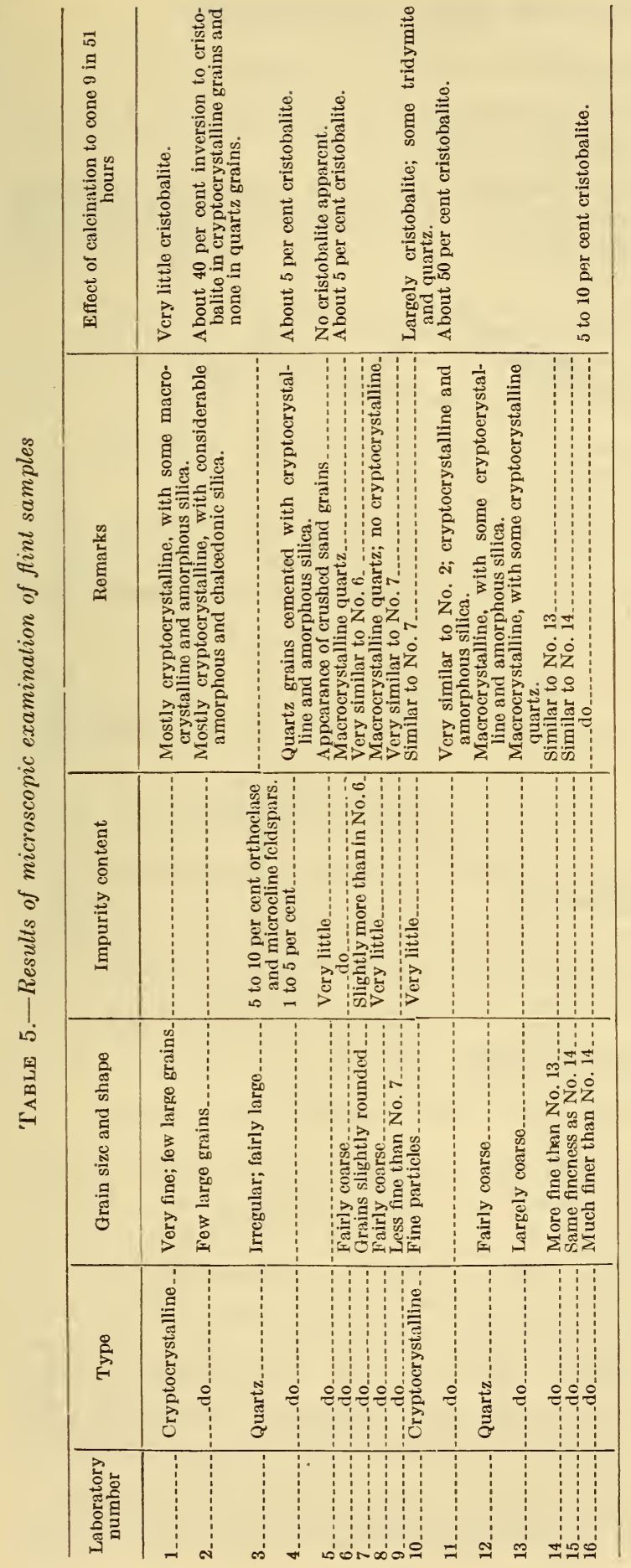




\section{EFFECTS OF SILICA INVERSIONS}

\section{THE CRYSTAL FORMS OF SILICA}

Silica occurs in seven crystal forms, the transformation behaviors of which have been carefully studied. ${ }^{7}$

The silica crystal transformation behaviors are shown by curves in Figure $2{ }^{8}$ and the temperatures of transformation, as determined by Fenner, are given in Table 6.

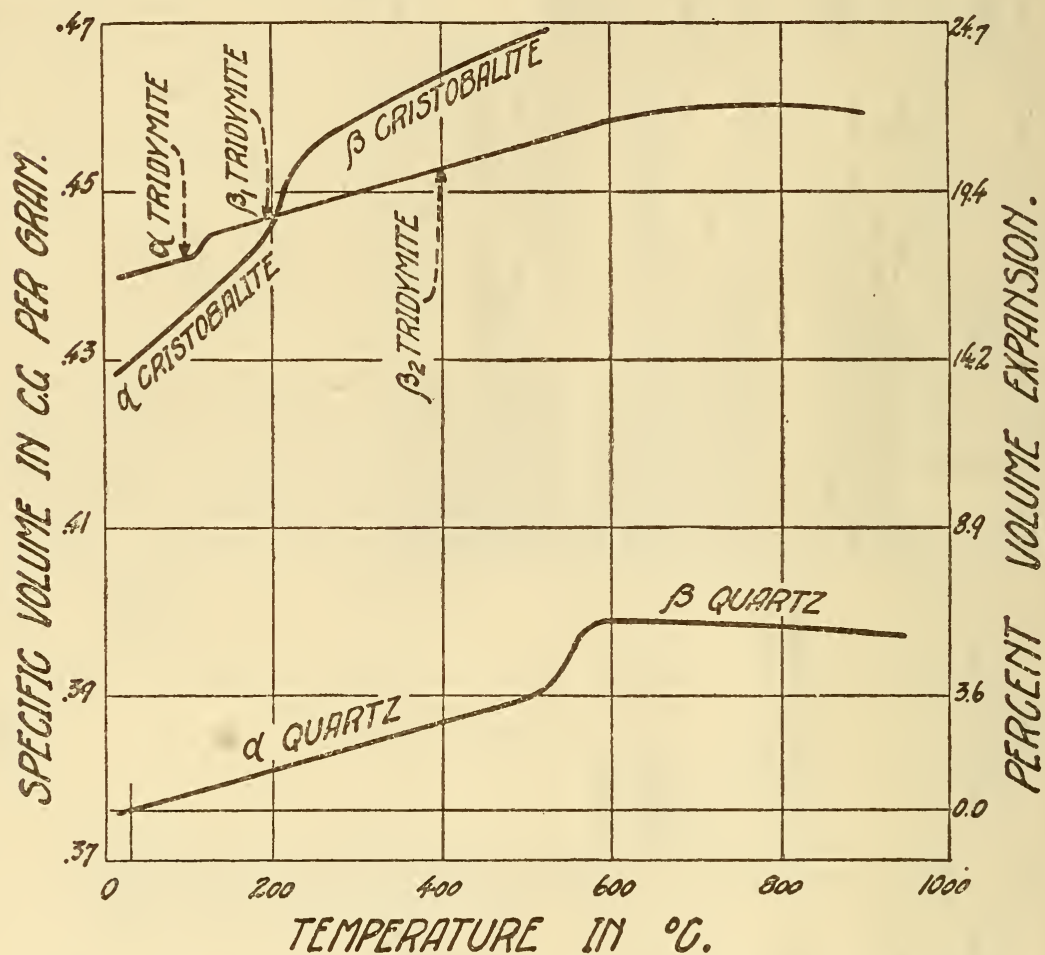

FIG. 2.-Thermal volume changes of silica, referred to quartz at $25^{\circ} \mathrm{C}$.

While tridymite and cristobalite may exist for indefinite periods of time at room temperatures, the low temperature, or a form of quartz is the only form of silica truly stable at these temperatures. A considerable expansion accompanies the transformation of a cristobalite to $\beta$ cristobalite in the temperature range of 220 to $275^{\circ}$ C., and a sudden expansion of about 2.2 per cent occurs at the inversion of a quartz to $\beta$ quartz at about $573^{\circ} \mathrm{C}$. These abrupt volume changes cause strains in a ceramic body containing free quartz when it is heated or cooled through the stages of crystal transformation.

\footnotetext{
7 "The stability relations of the silica minerals," C. N. Fenner, Am. Jour. Sci., 36, pp. 331-384; 1913.

8 From data of Fenner; also "Products of calcination of flint and chalcedony," Washburn and Navias, Jour. Amer. Cer. Soc., 5, p. 565; 1922; and B. S. Tech. Paper No. 116.
} 
TABLE 6.-Crystalline inversions of silica

\begin{tabular}{|c|c|c|}
\hline Inversion & $\begin{array}{l}\text { Approxi- } \\
\text { mate tem- } \\
\text { perature }\end{array}$ & Remarks \\
\hline $\begin{array}{l}\alpha \text { quartz to } \beta \text { quartz } \\
\alpha \text { tridymite to } \beta_{1} \text { tridymite } \\
\beta_{1} \text { tridymite to } \beta_{2} \text { tridymite } \\
\alpha \text { cristobalite to } \beta \text { cristobalite } \\
\beta \text { quartz to } \beta_{2} \text { tridymite } \\
\beta_{2} \text { tridymite to } \beta \text { cristobalite }\end{array}$ & $\begin{array}{r}{ }^{\circ} C . \\
575 \\
117 \\
163 \\
270-275 \\
870 \pm 10 \\
1,470 \pm 10\end{array}$ & $\begin{array}{l}\text { Rapid, reversible } \\
\text { Do. } \\
\text { Do. } \\
\text { Do. } \\
\text { Very sluggish, reversible. } \\
\text { Do. }\end{array}$ \\
\hline
\end{tabular}

The effects of silica inversion as indicated by heat effects and thermal expansion behaviors of typical flints and bodies containing them were studied and these data correlated with tests on the resistance of bodies to thermal shock.

\section{STUDY OF TRANSFORMATION HEAT EFFECTS}

(a) Method of Obserfation.-The transformation heat effects of typical flints and pulverized samples of fired bodies containing them were studied by comparing the rate of temperature rise observed in the samples and a standard neutral body when subjected to the same heating conditions. Alundum powder was used as the standard neutral body, and temperature differences were observed by the differential thermocouple method. ${ }^{9}$ A relative temperature depression was observed in the samples at the inversion points of silica, indicating that heat absorption accompanies the crystal transformations. The endothermic effect appeared to be roughly proportional to the percentage of silica in the samples.

(b) Descriptive References.-For this study comparative test bodies of vitreous china and semiporcelain compositions as shown in Table 7 were prepared. The vitreous china bodies are referred to as $\mathrm{V}$ and the semiporcelain bodies as $\mathrm{E}$, while the flints used are associated by number with the body references.

TABLE 7.-Batch compositions of bodies

\begin{tabular}{|c|c|c|c|c|}
\hline \multirow{2}{*}{ - Composition } & $\begin{array}{l}\text { Draw trial } \\
\text { body }\end{array}$ & \multicolumn{3}{|c|}{ Comparative test bodies } \\
\hline & \multicolumn{2}{|c|}{ Vitreous china } & $\begin{array}{l}\text { Sanitary } \\
\text { ware }\end{array}$ & $\begin{array}{l}\text { Semi- } \\
\text { porcelain } \\
\text { (earthen- } \\
\text { ware) }\end{array}$ \\
\hline $\begin{array}{l}\text { Flint } \\
\text { Maine feldspar } \\
\text { English ball clay } \\
\text { Florida kaolin } \\
\text { North Carolina kaolin } \\
\text { English china clay } \\
\text { Whiting }\end{array}$ & $\begin{array}{r}\text { Per cent } \\
36 \\
16 \\
7 \\
10 \\
30 \\
1\end{array}$ & $\begin{array}{c}\text { Per cent } \\
36 \\
18 \\
7.5 \\
8 \\
6 \\
23 \\
1.5\end{array}$ & $\begin{array}{r}\text { Per cent } \\
30 \\
26 \\
10 \\
8 \\
26\end{array}$ & $\begin{array}{r}\text { Per cent } \\
35 \\
13 \\
16 \\
8 \\
6 \\
22 \\
\end{array}$ \\
\hline Total & 100 & 100 & 100 & 100 \\
\hline
\end{tabular}

- Concerning the Annealing and Characteristics of Glass, A. Q. Tool and J. Valasek, B. S. Sci. Paper No. 358 . 
(c) Heat Effect Curves.-The curves shown in Figures 3 to 7, inclusive, were developed from data obtained by the heat effect determinations and are assembled to show the effects of different factors. For convenience in studying the heat effects in the desired temperature range the curves are referred to a common origin at $200^{\circ} \mathrm{C}$. The temperature differences shown, therefore, are not the actual temperature differences between the sample and neutral body, but differ-

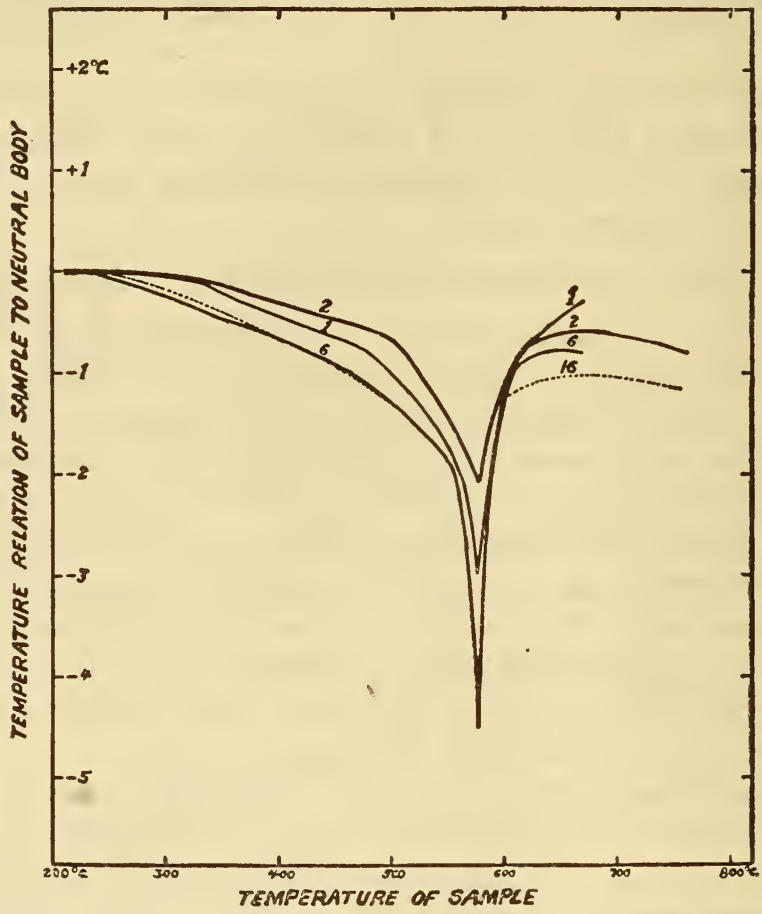

FIG. 3.-Effect of types of flint on transformation heat effects

Curve 1, American cryptocrystalline flint.

Curve 2, French cryptocrystalline flint.

Curve 6, American quartz flint.

Curve 16, American quartz flint of extreme fineness, prepared by water flotation.

ences as referred to an assumed zero at $200^{\circ} \mathrm{C}$. This is preferable because it is the heat effects above $200^{\circ} \mathrm{C}$. that are of interest, and these can thus be more clearly shown..$^{10}$

(d) Analysis of Transformation Heat Effect Data.(1) Effect of types of fints.-Referring to Figure 3, by comparing curves 1 and 2 to 6 and 16 it is seen that cryptocrystalline flints show less heat absorption at the quartz inversion point than quartz flints. This may be explained by their smaller percentage of free quartz.

10 The observed temperature differences between the sample and neutral body are affected by independent factors, such as heating conditions and thermocouple adjustments, which may not be readily duplicated between different tests. 
(2) Effect of fineness of flints.-By reference to Figure 4, comparing curves 2 and 6 to $\mathrm{F}$ and $\mathrm{S}$, also 16 to others, it is seen that no distinct heat effects may be attributed to fineness of grinding. A very finely ground sample, No. 16, shows heat absorption similar to S, a sample of the same type of flint crushed to pass a No. 20 sieve.

(3) Effect of crystal form of silica in white-ware bodies.-Referring to Figure 5, a comparison of curves $11 \mathrm{~V}$ to $5 \mathrm{~V}$ shows that bodies

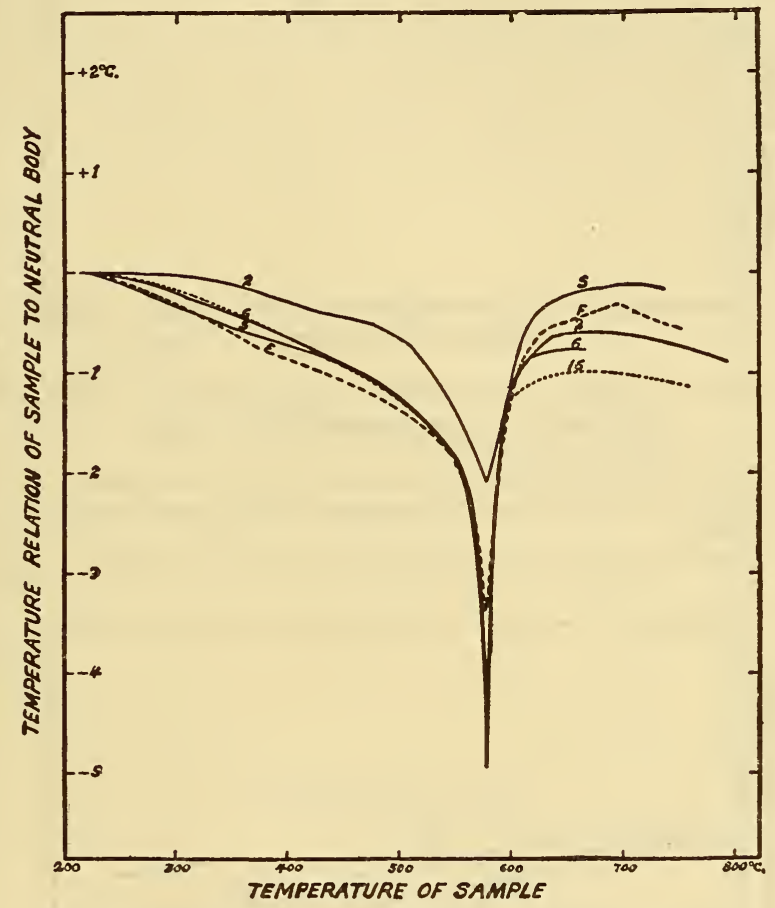

FIG. 4.-Effect of fineness of flint on transformation heat effects

Curve 2, French cryptocrystalline flint.

Curve 6 , American quartz flint.

Curve F, French flint similar to No. 2, crushed to pass a No. 20 sieve.

Curve S, quartz flint similar to No. 6, crushed to pass a No. 20 sieve.

Curve 16, American quartz flint of extreme fineness, prepared by water flotation.

containing cryptocrystalline flints show less heat absorption at the quartz inversion point than bodies containing quartz flints. By comparing curve CE to the others it is seen that a body containing cristobalite instead of quartz flint shows a marked absorption in the temperature range of the cristobalite inversion, 225 to $275^{\circ} \mathrm{C}$., and very little effect at the quartz inversion point. The gradual downward slope to about $573^{\circ} \mathrm{C}$., which is characteristic of curves for bodies containing quartz, is almost eliminated in bodies containing cristobalite. 


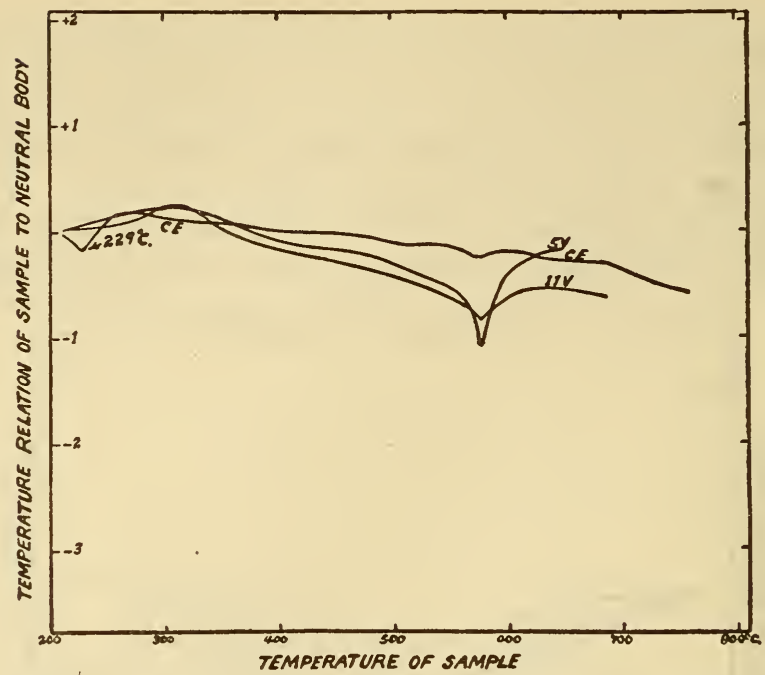

FIG. 5.-Effect of crystalline form of silica in whiteware bodies on transformation heat effects

Curve 5V, vitreous china body containing American quartz fint.

Curve $11 \mathrm{~V}$, vitreous china body containing French cryptocrystalline flint.

Curve CE, semiporcelain body containing pulverized cristobalite.

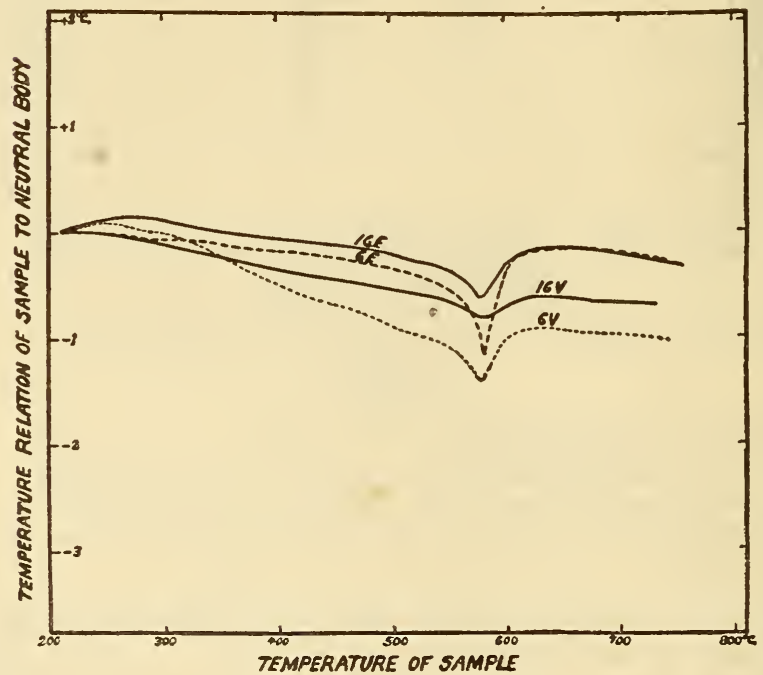

FiG. 6.-Effect of fineness of fint in white-ware bodies on transformation heat effects

Curve $6 \mathrm{E}$, semiporcelain body containing American quartz fint. Curve $6 \mathrm{~V}$, vitreous china body containing American quartz flint.

Curve $16 \mathrm{E}$, semiporcelain body containing American quartz flint of extreme fineness.

Curve $16 \mathrm{~V}$, vitreous china body containing American quartz flint of extreme fineness. 
(4) Effect of fineness of flint in white-ware bodies.-By reference to Figure 6, comparing curves $16 \mathrm{E}$ and $16 \mathrm{~V}$ to $6 \mathrm{E}$ and $6 \mathrm{~V}$, it is seen that fine grinding of the flint reduces the heat absorption in bodies at the quartz inversion points. This may be due to greater solution of quartz in the body or more extensive derelopment of mullite. ${ }^{11}$

It may be noted that in this case the ritreous china bodies show slightly greater heat effects than the semiporcelain bodies containing about equal percentages of the same flints.

(5) Peculiarities in heat effects.-Upon initial heating, a peculiar exothermic effect was observed in some cases, which was not observed upon reheating the sample without exposure to air. An

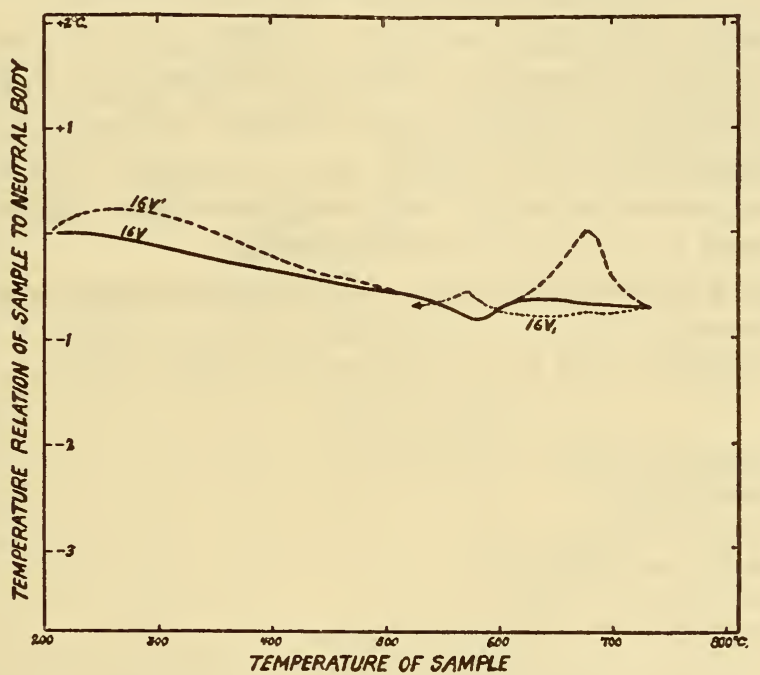

FIG. 7.-Peculiarities in heat effects

Curve $16 \mathrm{~V}^{\prime}$, thermal effects shown in initial heating of a vitreous china body containing flint No. 16 .

Curve $16 \mathrm{~V}$, thermal effects shown by the same body after reheating without exposure to air.

Curve $16 \mathrm{~V}_{1}$, thermal effects shown by the same body upon cooling after being heated above the temperature of the quartz inversion.

example of this peculiarity is shown in curve $16 \mathrm{~V}^{\prime}$ of Figure 7 . This effect is more often observed in very fine samples than in others.

The effects of retarded inversions on heating and cooling are shown in Figure 7 , by curves $16 \mathrm{~V}$ and $16 \mathrm{~V}_{1}$. In this case the maximum reaction on heating was observed at about $581^{\circ} \mathrm{C}$. and on cooling at $571^{\circ} \mathrm{C}$. The differences appear to be greatest with rapid heating ${ }^{12}$ and low concentration of quartz in the sample.

11 “"The system $\mathrm{Al}_{2} \mathrm{O}_{3} \cdot \mathrm{SiO}_{2}$," N. L. Bowen and J. W. Greig, J. Am. Cer. Soc., 7, No. 4, pp. 238-254; 1924 .

12 Fenner notes the transformation of $\beta$ to $\alpha$ quartz at $570^{\circ} \mathrm{C}$. Bates and Phelps find that both the $\alpha$ to $\beta$ and $\beta$ to $\alpha$ quartz transformations occur at $573.3^{\circ} \mathrm{C}$., under very slow heating. Physical Review, 18, second series, No. 2, pp. 115-116; August, 1921. 
(6) Effect of quartz solutions.-By comparing the general form of the curves for flint samples to the curves for bodies containing the flints, it is seen that the heat absorption of the bodies at the quartz inversion point is less than of the flints and relatively less than the proportion of flint contained in them. This would indicate that a part of the quartz is rendered ineffective in heat reaction by solution in the feldspar glass. However, in a ceramic body other factors, such as independent heat effects of the clay, may come into action, so that a direct comparison of the heat absorption between a flint and a body does not appear pertinent.

\section{STUDY OF THERMAL EXPANSION}

(a) MEтHOD.-Thermal expansion observations ${ }^{13}$ were made on white-ware bodies containing different flints by the light-wave interference method ${ }^{14}$ and the results plotted as per cent expansion against temperature. For these tests triangular prisms (fig. 12) having sides approximately 1 inch long and three-eighths inch high were prepared by pressing in plaster molds.

(b) Sample Reference Data.-The vitreous china, sanitary ware, and semiporcelain body compositions shown in Table 7 were used. The flint samples used in the bodies are listed below:

American cryptocrystalline Description of flint $\begin{gathered}\text { Laboratory } \\ \text { number }\end{gathered}$

American quartz rock

American quartz sand .

American sandrock, or quartzite

French cryptocrystalline.

American sandrock quartz of extreme fineness_._.

Cristobalite prepared by grinding a commercial silica brick to average

fineness. A microscopic examination indicated a composition of 80 per cent cristobalite, 10 per cent tridymite, and 10 per cent quartz_._._.

(c) Analysis of Curve Data on the Thermal Expansion of Bodies.-(1) Effect of type on body.-In the three types of bodies containing the same flint the thermal expansion near the quartz inversion temperature is approximately proportional to the flint content, as shown in Figure 8.

(2) Effect of type of flint contained in bodies.-Inspection of the thermal expansion curves in Figures 9 and 10 indicates that bodies containing cryptocrystalline flints show greater expansion in the cristobalite inversion range than quartz flints and less at the quartz inversion point. The effects are less distinct in the case of sanitary ware bodies (fig. 10) containing 30 per cent of flint than in the case of vitreous china bodies (fig. 9) containing 36 per cent flint.

${ }^{13}$ Determinations made by the interferometry section of the Bureau of Standards.

${ }_{14}$ Measurements of Thermal Dilation of Glass at High Temperatures, C. G. Peters and C. H. Cragoe, B. S. Sci. Paper No. 393; and Interference Methods for Standardizing and Testing Precision Gauge Blocks. C. G. Peters and H. S. Boyd, B. S. Sci. Paper No. 436. 


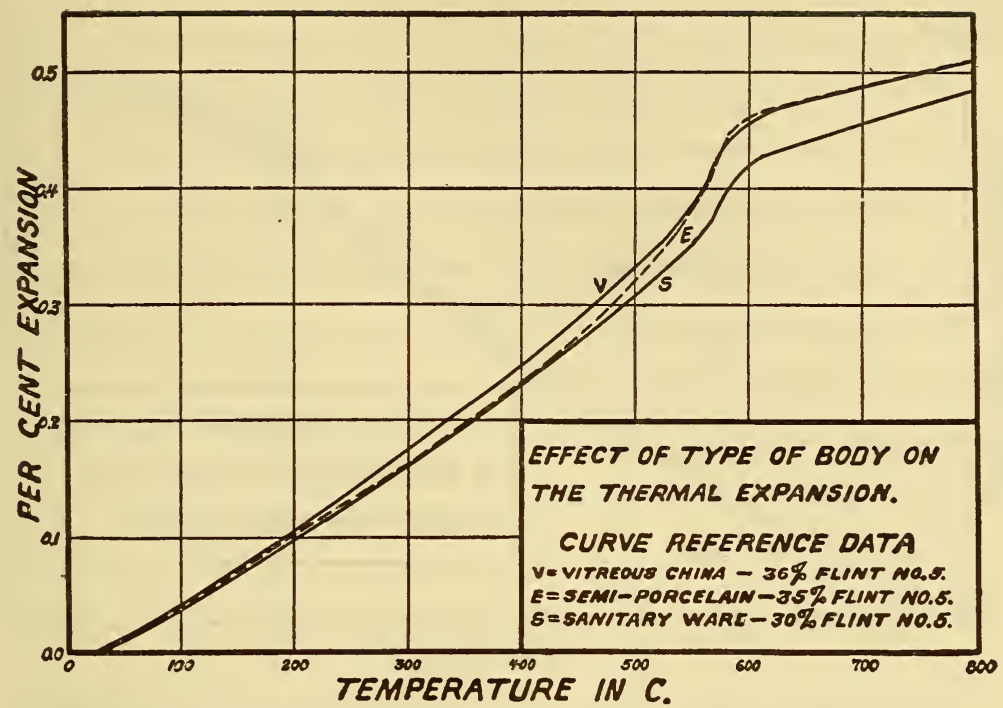

Fra. 8.-Effect of variation of fint content in bodies on the thermal expansion

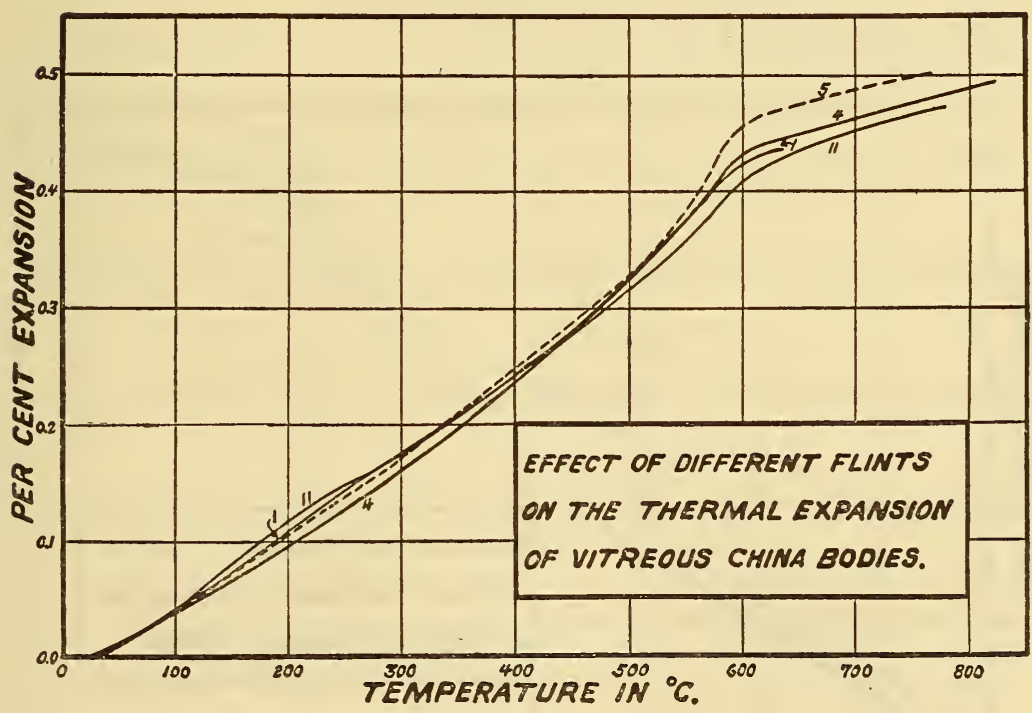

FIG. 9.-Effect of type of fint on the thermal expansion of vitreous china bodies

Curve 1, body containing American cryptocrystalline flint No. 1.

Curve 11, body containing French cryptocrystalline flint No. 11 .

Curve 4, body containing American quartz flint No. 4.

Curve 5, body containing American quartz flint No. 5 . 


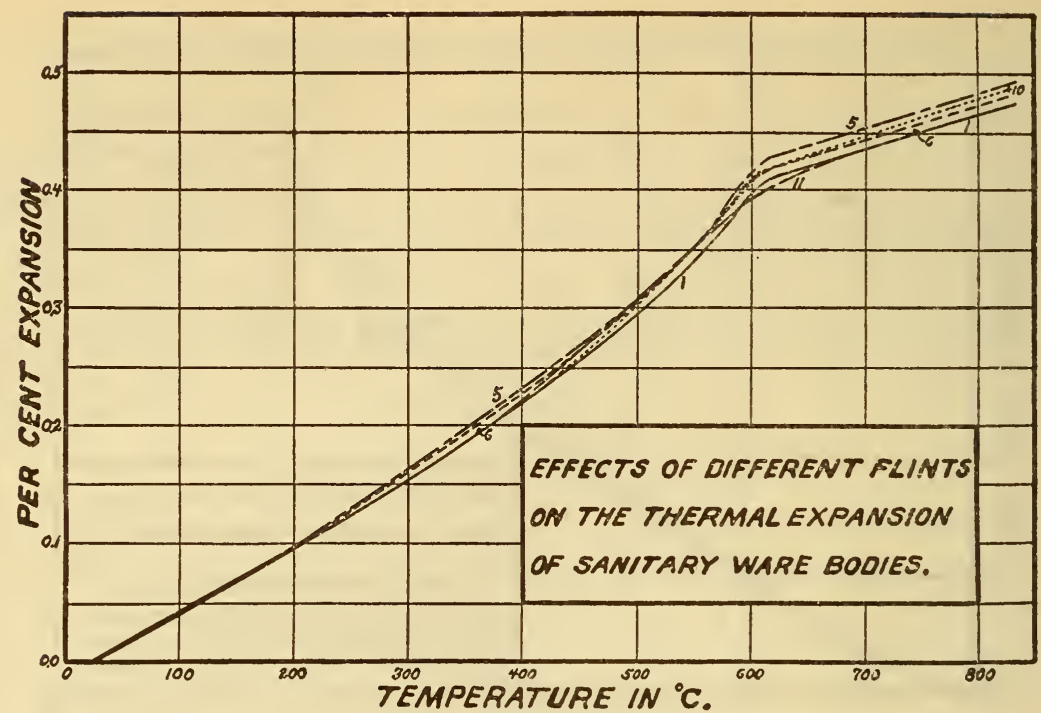

FIG. 10.-Effect of type of fint on the thermal expansion of sanitary-ware bodies

Curve 1, body containing American cryptocrystalline flint No. 1.

Curve 10, body containing American cryptocrystalline flint No. 10.

Curve 11, body containing French cryptocrystalline flint No. 11.

Curve 5, body containing American quartz flint No. 5 .

Curve 6, body containing American quarts flint No. 6 .

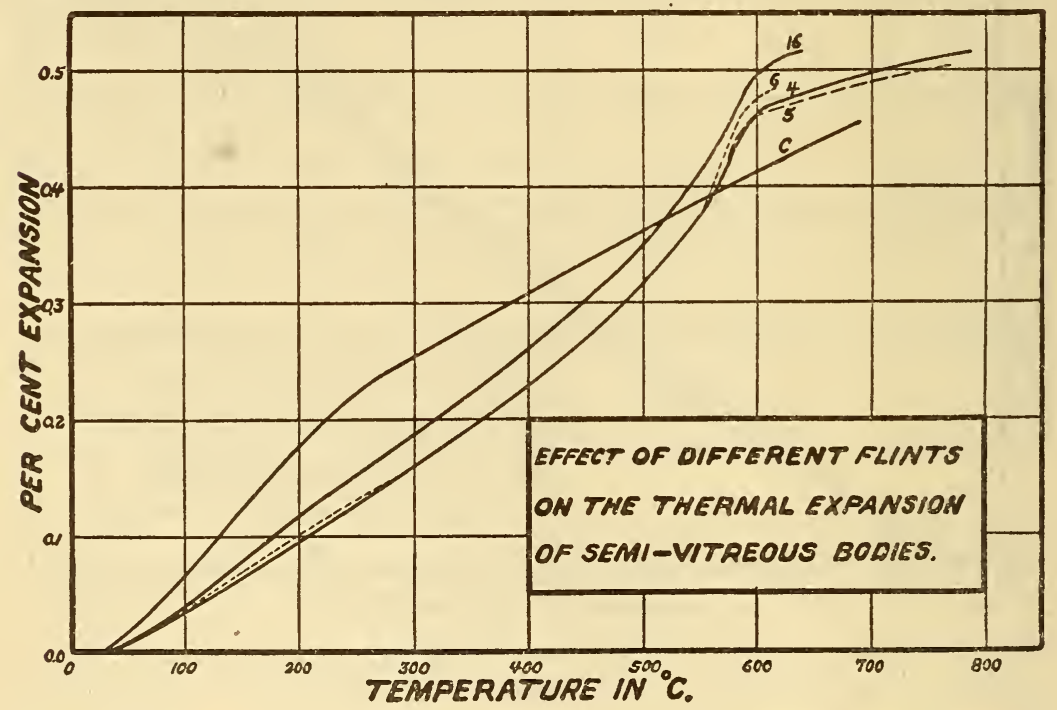

FIG. 11.-Effect of type of fint on the thermal expansion of semivitreous bodies

Curve 4, body containing American quarts flint No. 4.

Curve 5 , body containing American quartz flint No. 5 .

Curve 6, body containing American quartz flint No. 6 .

Curve 16, body containing American quarts flint of extreme fineness, No. 16.

Curve C, body containing pulverized cristobalite. 



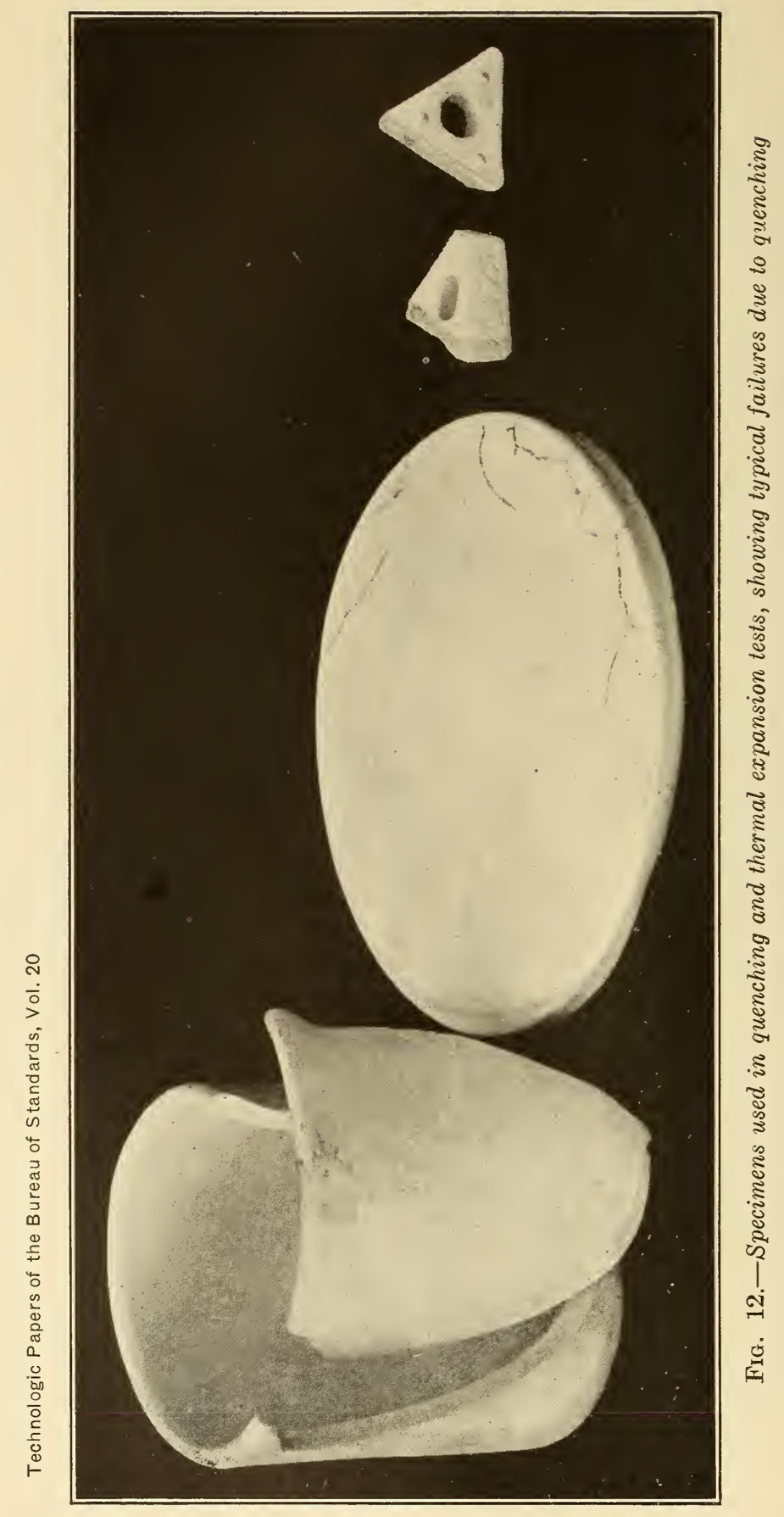


(3) Effect of crystal form of silica.-By comparing curve $C$ to others in Figure 11 it is seen that the thermal expansion of the body containing cristobalite differs from those containing quartz in the following respects: Greater expansion through the cristobalite inversion temperature range; less expansion after the cristobalite inversion to the quartz inversion point; no abrupt change in the expansion at the quartz inversion point.

(4) Effect of fineness of fint.-Comparing the slopes of curve 16 to curves 4,5 , and 6 at the silica inversion points (fig. 11) indicates that extreme fineness of the flint in bodies causes a slightly higher rate of expansion in the temperature range of the cristobalite inversion and a lower rate in the range of the quartz inversion. It may be noted that the porosity of the bodies containing the very fine flint was 11 per cent, as compared to 19 per cent for other bodies. This difference in the vitreous character of the body structure may account in part for a difference in thermal expansion.

\section{COMPARISON OF RESULTS OF HEAT EFFECT AND THERMAL EXPANSION STUDIES}

It is observed that the different factors affecting the heat absorption of a body affect the thermal expansion in a similar manner.

\section{STUDY OF RESISTANCE OF BODIES TO THERMAL SHOCK}

(a) Tests for Resistance to Thermal Shock.-Tests for resistance of bodies to thermal shock were made by cooling test specimens from $600^{\circ} \mathrm{C}$. by quenching in air and from $200^{\circ} \mathrm{C}$. by quenching in water at room temperature. The tests were intended to differentiate between failures due to the volume change incident to the quartz inversion at about $573^{\circ} \mathrm{C}$. and the volume changes occurring below $200^{\circ} \mathrm{C}$.

For these tests the same types of bodies and the same flints were used as for the thermal expansion determinations. Cups were jiggered for the air-quenching tests and small disks for the waterquenching tests. The shapes of the test pieces and characteristic failures are shown in Figure 12.

(b) AIr-Quenching Tests.-- (1) Testing procedure.-The test cups were placed directly into a furnace heated to about $600^{\circ} \mathrm{C}$. and allowed to remain for one-half hour, after which they were removed from the furnace and allowed to cool in air at room temperature. Failure was accompanied by peculiar "clicks." These "clicks" were heard early in the cooling period and never during the heating period, when the rate of temperature change was lower. When the cups were heated to a slightly higher temperature, no higher percentage of failures was observed, but the clicking occurred later after removal from the furnace. Failure occurred with a smooth con- 
choidal fracture, the detection of which sometimes required dipping the specimen in red ink and washing with water.

These observations indicate that the greatest strain occurs at the quartz inversion point, and that it is affected by the rate of temperature change at this point.

(2) Observations on air-quenching tests. - The results of the tests point to the following conclusions: No difference in resistance to failure between vitreous and relatively porous bodies was apparent. Fineness of grinding of the flint was found to increase the resistance to failure. Bodies containing cryptocrystalline flints were found slightly more resistant to failure than those containing quartz flints. A body containing cristobalite showed a much greater resistance than others.

(c) Water-Quenching Tests.-(1) Testing procedure.-Immersing the disks, heated to $200^{\circ} \mathrm{C}$., in water at about $25^{\circ} \mathrm{C}$. was found a sufficiently severe test for resistance to failure by quenching in the case of vitreous china and sanitary ware bodies, but not severe enough for semiporcelain bodies. The semiporcelain bodies were therefore quenched from successive temperature intervals of $25^{\circ} \mathrm{C}$. above $200^{\circ} \mathrm{C}$., which was found a satisfactory method of differentiating between groups of this type.

Failure on quenching was shown by irregular cracks, differing in appearance from the smooth, conchoidal fractures observed in failures by air quenching. The test specimens generally gave a deadened ring after the first quenching, even when no fracture could be detected by dipping in red ink and washing with water.

(2) Observations on water-quenching tests.- The results of the tests by water quenching point to the following conclusions: Porous bodies are more resistant to failure than vitreous bodies. Fineness of grinding of flint reduces the porosity of a body, and consequently its resistance to failure. Bodies containing quartz flints show greater resistance to failure than bodies containing cryptocrystalline flints, while a body containing cristobalite occupies an intermediary position as regards resistance to failure.

(d) Conclusions. - The tests for resistance of bodies to thermal shock indicate that cryptocrystalline flints promote resistance in the temperature range near the quartz inversion point, while quartz flints appear to promote resistance in the temperature range near the cristobalite inversion.

\section{EFFECTS OF FLINTS ON THE FIRING BEHAVIOR OF BODIES}

\section{RELATIVE FUSIBILITY IN A "CONE 4 " BODY}

(a) Body And BAtch Compositions.-The effect of the flints on the fusibility of glaze compositions was studied by using different flints in glaze batches of the composition of the Seger cone No. 4. 
Seger cone No. 4 has the molecular composition of

$$
\left.\begin{array}{l}
0.3 \mathrm{~K}_{2} \mathrm{O} \\
0.7 \mathrm{CaO}
\end{array}\right\} 0.5 \mathrm{~A}_{2} \mathrm{O}_{3} \quad 4 \mathrm{SiO}_{2}
$$

The batch composition used in preparing the bodies was:

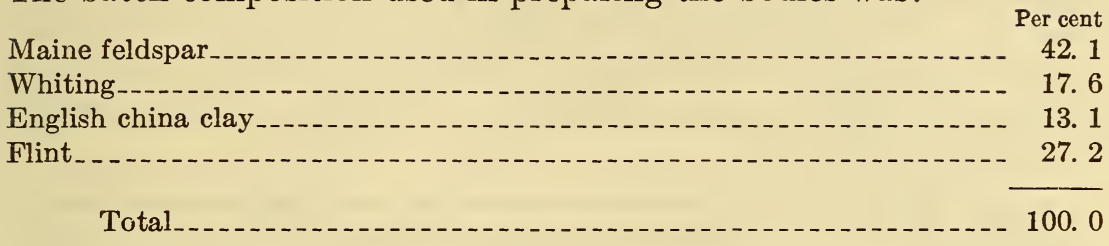

(b) Testing Procedure.-Each batch was first mixed dry and then with sufficient water to develop the best working consistency. The plastic material was formed into standard sized cones in a mold. Several cones from each batch were fired in a sagger, together with six standard No. 4 cones, and all were set within an area about 8 inches square. The standard cones were all deformed to about the same degree, showing very uniform heat distribution in the sagger.

(c) Results.-The maximum difference in heat effect between the flints included was estimated as less than three-quarters of a cone, representing about $15^{\circ} \mathrm{C}$. The softening effects observed upon the various cones indicated that the flints might be graded into the following five groups, named in the order of their fusibility: (1) Standard cone 4; (2) sample No. 15; (3) Nos. 2, 10, 4, 7, 9, and 5 ; (4) No. 11 ; (5) Nos. 6 and 1.

The results do not permit of definite conclusions regarding the effects of type of flint. Fineness of grinding and the presence of impurities, however, appear to promote fusibility.

\section{DRAW TRIAL STUDY ON A VITREOUS CHINA BODY}

(a) Preparation of Test Specimens.-The different flints were used in a vitreous china body of the composition as indicated in Table 7. The bodies were prepared by hand mixing and pressed into $21 / 2$ by 1 by 1 inch test pieces.

(b) Method of Firing.-Duplicate test pieces of each of the bodies were fired in ciosed cranks to cones $6,8,10,12$, and 14 and cooled in sand. The time between draws varied from $1 \frac{1}{2}$ to $2 \frac{1}{2}$ hours and the total time of firing was 50 hours.

(c) Physical Data.- The following physical data were determined on the fired test pieces: (1) Volume burning shrinkage, (2) bulk specific gravity, and (3) apparent porosity. The volumes of the test pieces dried at $110^{\circ} \mathrm{C}$. were measured by means of a mercury volumeter, and of the fired test pieces by the difference of weight in air and water. Apparent porosity was determined on the fired test pieces by the water-absorption method, the air being first exhausted for 15 minutes by a partial vacuum of $2-\mathrm{mm}$ mercury column pres- 
sure. The specimens were boiled in water at a reduced pressure for 15 minutes and allowed to soak in water overnight before weighing.

(d) Discussion of Results. - The results of the tests on bodies containing the different flints are shown graphically in Figures 13, 14, and 15. Inspection of the curves points to the following conclusions:

Fine grinding of the flint and the presence of impurities causes high shrinkage and low porosity, as shown by the position of curves 16 and 3 in Figures 13 and 15.

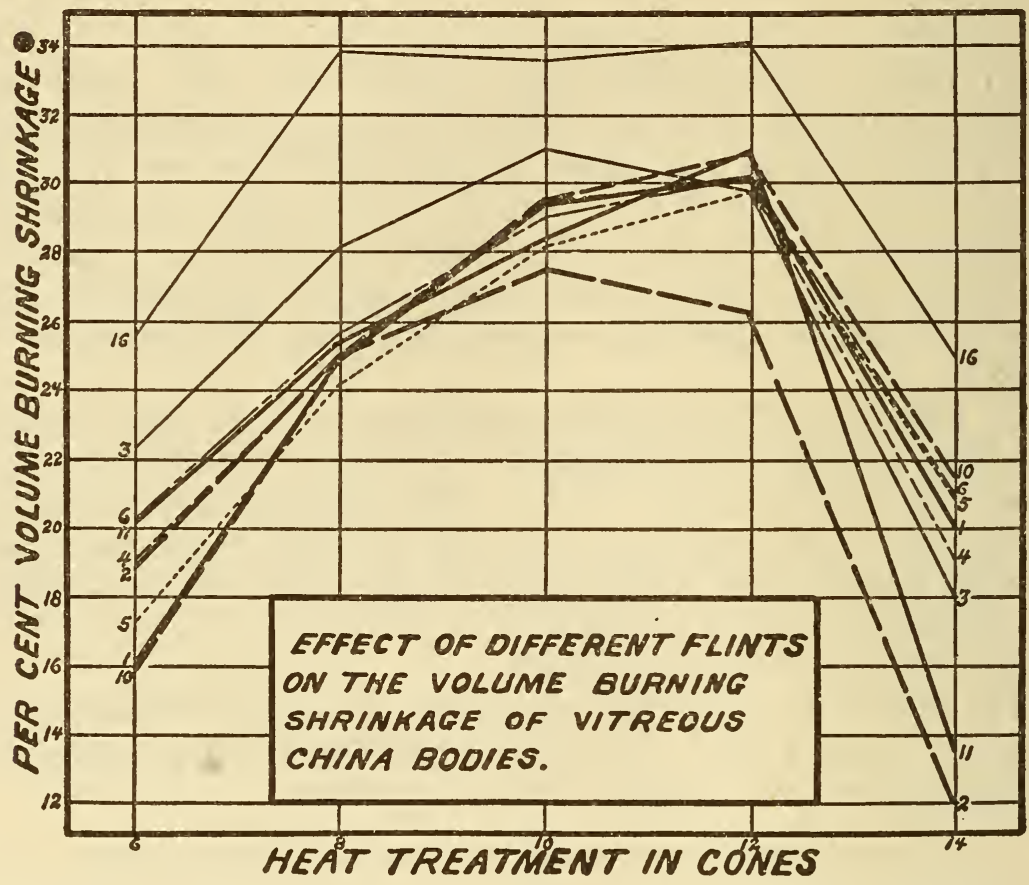

FIG. 13.-Progressive changes in volume burning shrinkage of vitreous china bodies containing typical flints

Curve 1, American cryptocrystalline flint No. 1.

Curve 10, American cryptocrystalline flint No. 10.

Curve 2, French cryptocrystalline flint No. 2.

Curve 11, French cryptocrystalline flint No. 11.

Curve 4, American quartz flint No. 4.

Curve 5, American quartz flint No. 5.

Curve 6, American quartz flint No. 6.

Curve 16, American quartz flint of extreme fineness, No. 16.

Curve 3, American quartz flint of relatively high impurity content, No. 3 .

Bodies containing cryptocrystalline flint indicate overfiring effects earlier than those containing quartz flints, as shown by the volume shrinkage and porosity behaviors.

The bulk specific gravity of bodies containing cryptocrystalline flints is generally lower than that of bodies containing quartz flints, the American cryptocrystalline flints producing bodies having the lowest bulk specific gravity up to cone 10 and the French the lowest above this temperature 


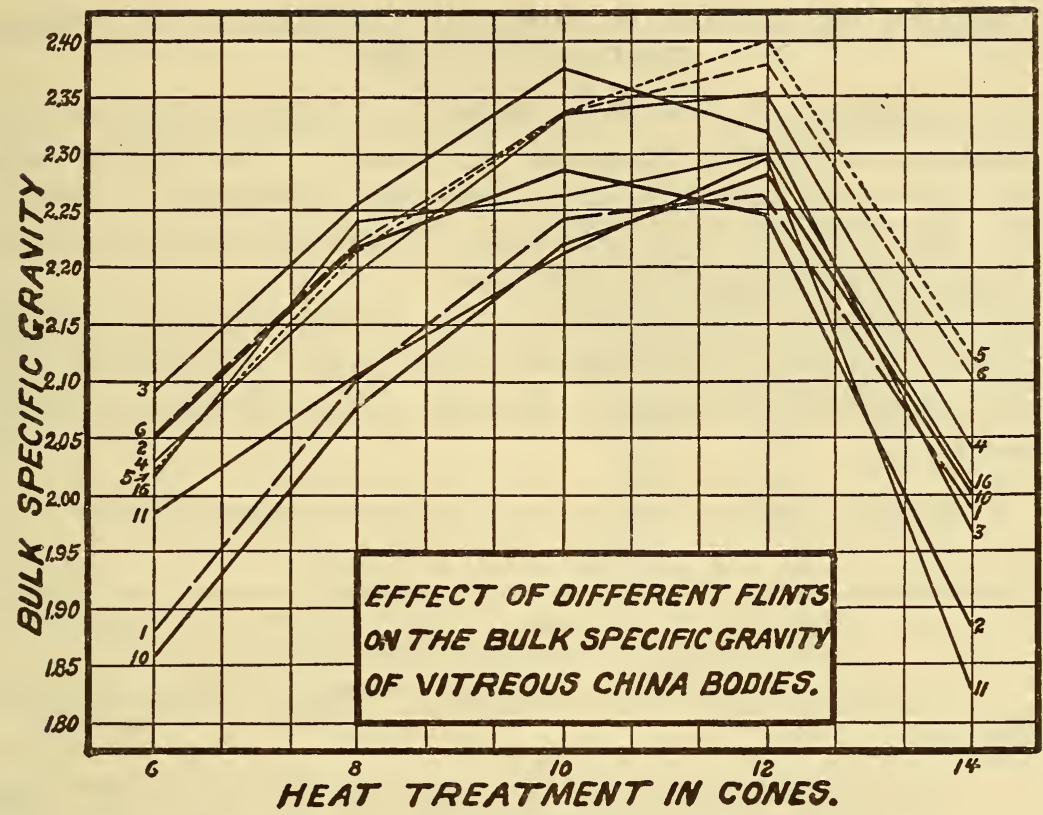

Fig. 14.-Effect of different fints on the bulk specific gravity of vitreous china bodies

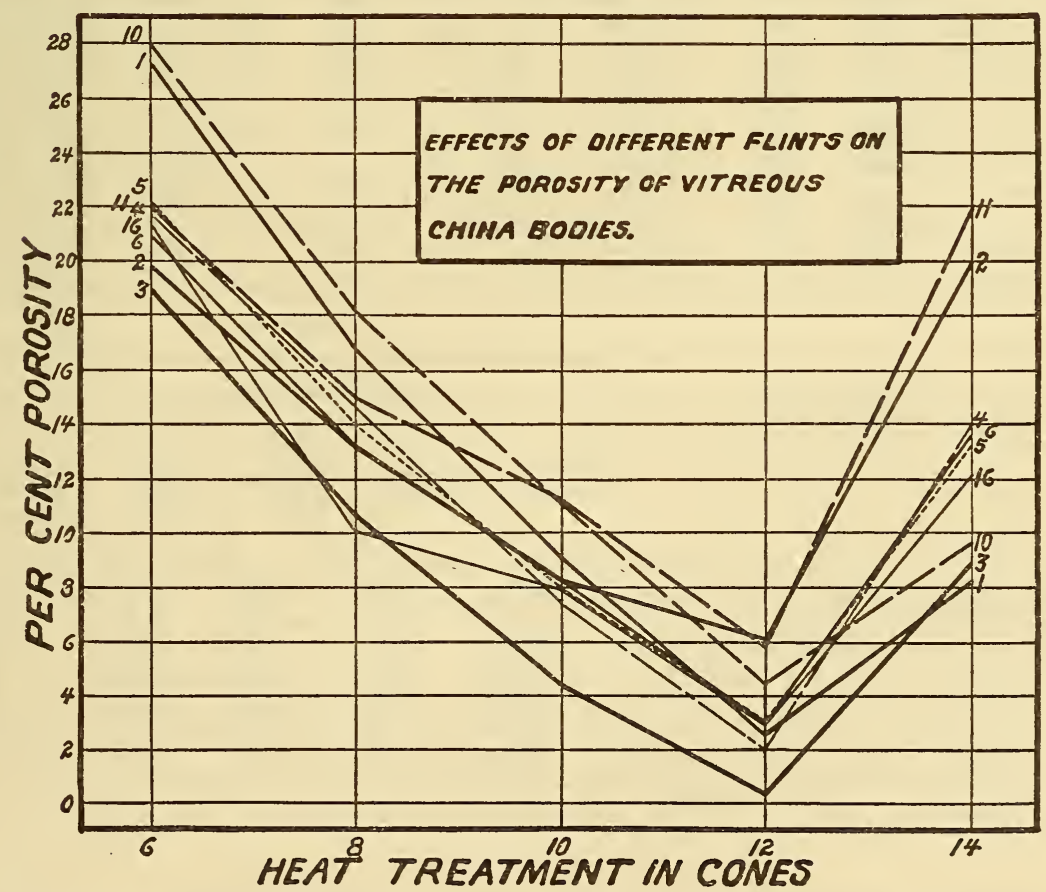

FIG. 15.-Effects of different fints on the porosity of vitreous china bodies 


\section{EFFECTS OF FLINTS ON PHYSICAL PROPERTIES OF TYPICAL WHITE-WARE BODIES}

(a) Reference Data.-Body references by type of body and flint laboratory number are indicated in Table 8. 'I he $\mathrm{CE}$ reference applies to a semiporcelain body containing cristobalite instead of flint. The reference data include the method of mixing and cone of firing of the various series of bodies.

(b) Method of Preparation.-The bodies were prepared by mixing in a ball mill or a blunger for three hours. The slip was then passed over an electromagnet, through a No. 100 sieve, and filter pressed.

TABLE 8.-Reference data and results of tests on white-ware bodies

A. VitREOUS CHINA BODIES

\begin{tabular}{|c|c|c|c|c|c|c|c|c|c|c|c|}
\hline \multirow{3}{*}{$\begin{array}{l}\text { Body } \\
\text { reference }\end{array}$} & \multicolumn{3}{|c|}{ Series 1} & \multicolumn{3}{|c|}{ Series 2} & \multicolumn{2}{|c|}{ Series 3} & \multicolumn{3}{|c|}{ Series 4} \\
\hline & \multicolumn{3}{|c|}{ Ball mill mixing cone 9} & \multicolumn{3}{|c|}{ Ball mill mixing cone 11} & \multicolumn{2}{|c|}{$\begin{array}{l}\text { Blunger mix- } \\
\text { ing cone } 11\end{array}$} & \multicolumn{3}{|c|}{ Ball mill mixing cone 12} \\
\hline & $\begin{array}{l}\text { Mod- } \\
\text { ulus of } \\
\text { rup- } \\
\text { ture }\end{array}$ & $\begin{array}{l}\text { Appar- } \\
\text { ent } \\
\text { poros- } \\
\text { ity }\end{array}$ & $\begin{array}{c}\text { Linear } \\
\text { shrink- } \\
\text { age }\end{array}$ & $\begin{array}{l}\text { Mod- } \\
\text { ulus of } \\
\text { rup- } \\
\text { ture }\end{array}$ & $\begin{array}{c}\text { Appar- } \\
\text { ent } \\
\text { poros- } \\
\text { ity }\end{array}$ & $\begin{array}{l}\text { Linear } \\
\text { shrink- } \\
\text { age }\end{array}$ & $\begin{array}{l}\text { Mod- } \\
\text { ulus of } \\
\text { rup- } \\
\text { ture }\end{array}$ & $\mid \begin{array}{c}\text { Appar- } \\
\text { ent } \\
\text { poros- } \\
\text { ity }\end{array}$ & $\begin{array}{l}\text { Mod- } \\
\text { ulus of } \\
\text { rup- } \\
\text { ture }\end{array}$ & $\begin{array}{l}\text { Appar- } \\
\text { ent } \\
\text { poros- } \\
\text { ity }\end{array}$ & $\begin{array}{l}\text { Linear } \\
\text { shrink- } \\
\text { age }\end{array}$ \\
\hline $\begin{array}{l}10 \mathrm{~V} \\
1 \mathrm{~V}-\ldots \\
11 \mathrm{~V} \\
11 \mathrm{~V}\end{array}$ & \begin{tabular}{|r|} 
Lbs/in.2. \\
6,100 \\
5,800 \\
5,500 \\
5,400
\end{tabular} & \begin{tabular}{|r|} 
Per cent \\
9.3 \\
16.8 \\
11.1 \\
12.5
\end{tabular} & $\begin{array}{r}\text { Per cent } \\
9.0 \\
7.5 \\
7.6 \\
7.6\end{array}$ & $\begin{array}{r}\text { Lbs/in. } \\
8,500 \\
7,800 \\
7,400 \\
7,600\end{array}$ & $2 \mid \begin{array}{c}\text { Per cent } \\
0.10 \\
.24 \\
.39 \\
.42\end{array}$ & $\begin{array}{c}\text { Per cent } \\
9.9 \\
9.6 \\
8.2 \\
8.6\end{array}$ & $\begin{array}{r}\text { Lbs/in. } .^{2} \\
4,300 \\
5,900 \\
5,200 \\
4,400 \\
5,700\end{array}$ & $\mid$\begin{tabular}{r|r} 
Per cent \\
5.2 \\
5.2 \\
5.5 \\
6.6 \\
4.4
\end{tabular} & $\begin{array}{c}\text { Lbs/in. } .^{2} \\
7,300 \\
6,700 \\
7,200 \\
7,500 \\
8,100\end{array}$ & $\begin{array}{c}\text { Per cent } \\
0.14 \\
.20 \\
2.00 \\
1.80 \\
.17\end{array}$ & 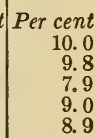 \\
\hline $\begin{array}{l}6 \mathrm{~V} \\
7 \mathrm{~V}-\mathrm{V}^{-} \\
9 \mathrm{~V}\end{array}$ & $\begin{array}{l}6,300 \\
5,600 \\
5,100\end{array}$ & $\begin{array}{r}9.2 \\
11.9 \\
14.2\end{array}$ & $\begin{array}{l}8.1 \\
7.4 \\
7.1\end{array}$ & $\begin{array}{l}9,700 \\
8,300 \\
7,300\end{array}$ & $\begin{array}{r}.14 \\
.14 \\
1.22\end{array}$ & $\begin{array}{l}8.2 \\
8.8 \\
8.5\end{array}$ & 4,900 & 4.3 & $\begin{array}{l}8,100 \\
8,000 \\
6,700\end{array}$ & \multirow{2}{*}{$\begin{array}{r}.20 \\
.15 \\
2.32 \\
.17 \\
.15\end{array}$} & $\begin{array}{l}8.8 \\
8.6 \\
8.4\end{array}$ \\
\hline $\begin{array}{l}16 \mathrm{~V} \\
17 \mathrm{~V}\end{array}$ & 5,200 & 9.8 & 8.0 & 8,300 & .13 & 8.7 & 4,700 & 4.4 & $\begin{array}{l}8,000 \\
7,100\end{array}$ & & $\begin{array}{l}9.6 \\
8.8\end{array}$ \\
\hline Average.. & 5,600 & 11.8 & 7.8 & 8,100 & .35 & 8.8 & 5,000 & 5.0 & 7,500 & .73 & 9.0 \\
\hline \multirow{3}{*}{\multicolumn{4}{|c|}{ Body reference }} & \multicolumn{8}{|c|}{ Series 5} \\
\hline & & & & \multicolumn{8}{|c|}{ Ball mill mixing cone 11} \\
\hline & & & & & $\begin{array}{l}\text { Modulus } \\
\text { f rupture }\end{array}$ & \multicolumn{2}{|c|}{$\begin{array}{l}\text { Apparent } \\
\text { porosity }\end{array}$} & $\begin{array}{l}\text { Bulk } \\
\text { specific } \\
\text { gravity }\end{array}$ & \multicolumn{2}{|c|}{$\begin{array}{l}\text { True } \\
\text { specific } \\
\text { gravity }\end{array}$} & $\begin{array}{l}\text { Sealed } \\
\text { pores }\end{array}$ \\
\hline $\begin{array}{l}10 \mathrm{~V} \\
\text { IV } \\
2 \mathrm{~V} \\
11 \mathrm{~V} \\
4 \mathrm{~V} \\
5 \mathrm{~V} \\
6 \mathrm{~V}\end{array}$ & & & & & $\begin{array}{r}\text { Lbs/in. }{ }^{2} \\
7,100 \\
7,300 \\
8,000 \\
8,300 \\
9,500 \\
10,300 \\
9,000\end{array}$ & Perc & $\begin{array}{l}e n t \\
0.13 \\
.14 \\
.55 \\
3.21 \\
.32 \\
1.02 \\
.22\end{array}$ & $\begin{array}{l}2.34 \\
2.35 \\
2.35 \\
2.32 \\
2.41 \\
2.41 \\
2.41\end{array}$ & & $\begin{array}{l}510 \\
493 \\
510 \\
501 \\
530 \\
540 \\
535\end{array}$ & $\begin{array}{r}\text { Per cent } \\
6.7 \\
5.7 \\
6.0 \\
4.4 \\
4.2 \\
4.5 \\
4.6\end{array}$ \\
\hline Average & & & & $\ldots$ & 8,500 & & .80 & 2.37 & & 517 & 5.2 \\
\hline
\end{tabular}


TABLE 8.-Reference data and results of tests on white-ware bodies-Continued B. SANITARY WARE BODIES

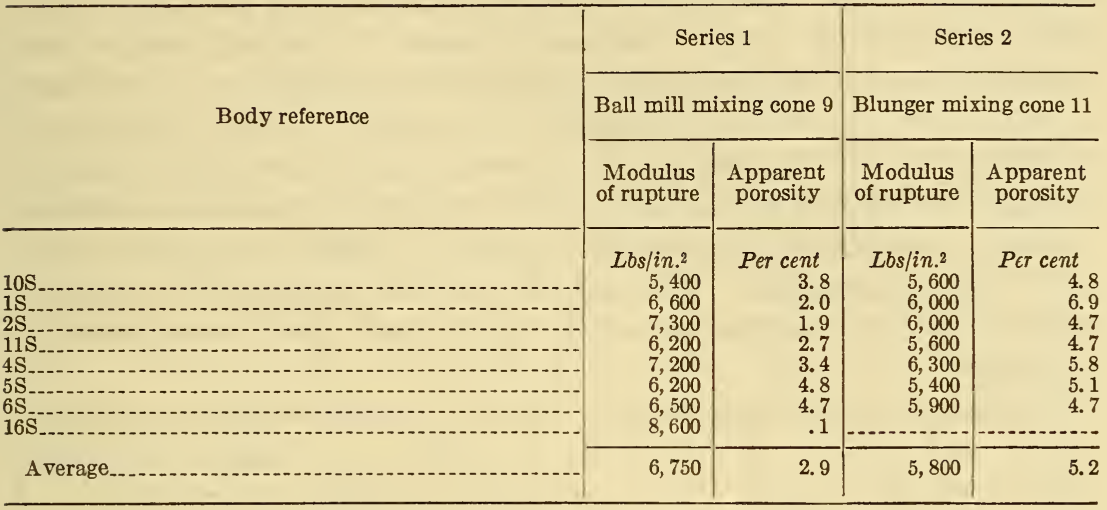

C. SEMIPORCELAIN BODIES (EARTHENWARE)

\begin{tabular}{|c|c|c|c|c|c|}
\hline \multirow{3}{*}{ Body reference } & \multicolumn{5}{|c|}{ Series 1} \\
\hline & \multicolumn{5}{|c|}{ Ball mill mixing cone 9} \\
\hline & $\begin{array}{l}\text { Modulus } \\
\text { of rupture }\end{array}$ & $\begin{array}{l}\text { Apparent } \\
\text { porosity }\end{array}$ & $\begin{array}{l}\text { Bulk } \\
\text { specific } \\
\text { gravity }\end{array}$ & $\begin{array}{l}\text { True } \\
\text { specific } \\
\text { gravity }\end{array}$ & $\begin{array}{l}\text { Sealed } \\
\text { pores }\end{array}$ \\
\hline $10 \mathrm{E}$ & $\begin{array}{c}L b s / i n .^{2} \\
5,600\end{array}$ & $\begin{array}{c}\text { Per cent } \\
19.9\end{array}$ & 2.06 & & Per cent \\
\hline $\begin{array}{l}10 \mathrm{E}- \\
2 \mathrm{E} \\
2 \mathrm{E}\end{array}$ & $\begin{array}{l}4,700 \\
4,700\end{array}$ & $\begin{array}{l}19.2 \\
18.2\end{array}$ & $\begin{array}{l}2.08 \\
2.09\end{array}$ & $\begin{array}{l}2.570 \\
2.549\end{array}$ & $\begin{array}{l}0.0 \\
0.0\end{array}$ \\
\hline $11 \mathrm{E}$ & 4,900 & 18.8 & 2.06 & & 0.0 \\
\hline 只 & 3,400 & 17.9 & 2.14 & 2.578 & (n) \\
\hline $\begin{aligned} 9 \\
-1\end{aligned}$ & $\begin{array}{l}4,900 \\
4,500\end{array}$ & $\begin{array}{l}18.6 \\
19.4\end{array}$ & $\begin{array}{l}2.12 \\
2.07\end{array}$ & & $\begin{array}{l}0.0 \\
0.0\end{array}$ \\
\hline $16 \mathrm{E}$ & 6,700 & 10.7 & 2.30 & 2.523 & 0.0 \\
\hline $\mathrm{CE}$ & 3,000 & 19.0 & 2.01 & 2.483 & 0.0 \\
\hline A verage.... & 4,700 & 17.9 & 2.10 & 2. 548 & 0.0 \\
\hline
\end{tabular}

(c) Physical Data.-The physical properties determined on the fired test pieces included (1) modulus of rupture, (2) apparent porosity, (3) linear shrinkage, and (4) in some cases bulk and true specific gravities. Microscopic examinations were also made on some of these specimens.

(d) Discussion of Results.-The results of the tests are shown in Table 8. At cone 9 no distinct difference in vitrification can be attributed to the type of flint used in a body. At cones 11 and 12 the bodies containing quartz flints show slightly greater strength than those containing cryptocrystalline flints. Bodies prepared by ball mill mixing show more advanced vitrification than bodies mixed in a blunger, indicating that the grinding effect of ball mill mixing is material.

Fineness of grinding of the flint materially lowers the maturing temperature of a body. A body containing the very fine flint, No. 
16, indicated heat treatment at cone 9 equivalent to that shown by bodies containing commercial potters' flints fired to cone 12. This body did not show marked overfiring effects at cone 12, indicating a considerable firing range. Greater fineness of grinding within commercial limits causes greater strength and lower porosity, as indicated in bodies $7 \mathrm{~V}$ and $9 \mathrm{~V}$, in which the flints differ only in fineness of grinding. It should be noted, however, that the slight grinding incident to ball mill mixing may obscure these comparative relations.

Bodies containing cristobalite instead of flint are found of low and variable strength. The specific gravity apparently is slightly lowered by the substitution, while the porosity does not seem to be affected.

The microscopic examination showed greater solution of quartz grains and greater development of mullite in bodies containing cryptocrystalline flints than in bodies containing quartz flints. A body containing the very finely ground quartz flint, No. 16, showed these effects more distinctly than others, indicating that fine yrinding promotes solution. The body containing cristobalite showed considerable solution of cristobalite crvstals but no development of mullite.

\section{SUMMARY}

1. All the flints examined contained over 94 per cent $\mathrm{SiO}_{2}$ and more than half over 99 per cent. The chief impurities found were $\mathrm{Fe}_{2} \mathrm{O}_{3}$ and $\mathrm{CaO}$. $\mathrm{Fe}_{2} \mathrm{O}_{3}$ varied from 0.03 to 0.12 per cent, while $\mathrm{CaO}$ was usually low or absent in American flints and averaged 0.42 per cent in French flints.

2. Most of the commercial flints were ground to such a degree of fineness that over half of the material would pass a theoretical No. 1,000 sieve and over 95 per cent a No. 325 sieve.

3. The specific gravity of the French flints is lower than that of American flints and is reduced more by calcination. The specific gravity of American cryptocrystalline flints is not appreciably lower than of American quartz flints.

4. Microscopic examinations of flint samples before and after calcination to cone 9 showed a considerable development of cristobalite during firing, the cryptocrystalline flints showing greater development than quartz flints.

5. A study of silica inversion behavior by means of heat absorption and thermal expansion data showed the effects of quartz inversion at about $573^{\circ} \mathrm{C}$., depending apparently on the amount of free quartz in the sample. Correlated tests on resistance of bodies to thermal shock showed least resistance at about $573^{\circ} \mathrm{C}$. and indicated that quartz flints promoted weakness at this temperature.

6. Cryptocrystalline flints do not materially lower the maturing temperature of a body, but cause overfiring effects earlier than quartz 
flints. The bulk specific gravity of bodies is reduced by the use of cryptocrystalline flints.

7. Fine grinding and the presence of impurities in the flint affects the firing behavior of a body more than the type of flint used. The most important effect of the type of flint is shown by the thermal expansion behavior of bodies in which it is used.

8. Quartz flints will produce bodies having greater resistance to thermal shock at temperatures below $200^{\circ} \mathrm{C}$; ; for temperatures above $573^{\circ}$ C. cryptocrystalline quartz will give better results. Excessive amounts of impurities will tend to lower the refractoriness, and wellvitrified bodies may show the mechanical weakness caused by overfiring. Fine grinding of a relatively pure quartz flint lowers the maturing temperature of a body without significantly affecting the vitrification range.

Washington, August 7, 1925. 